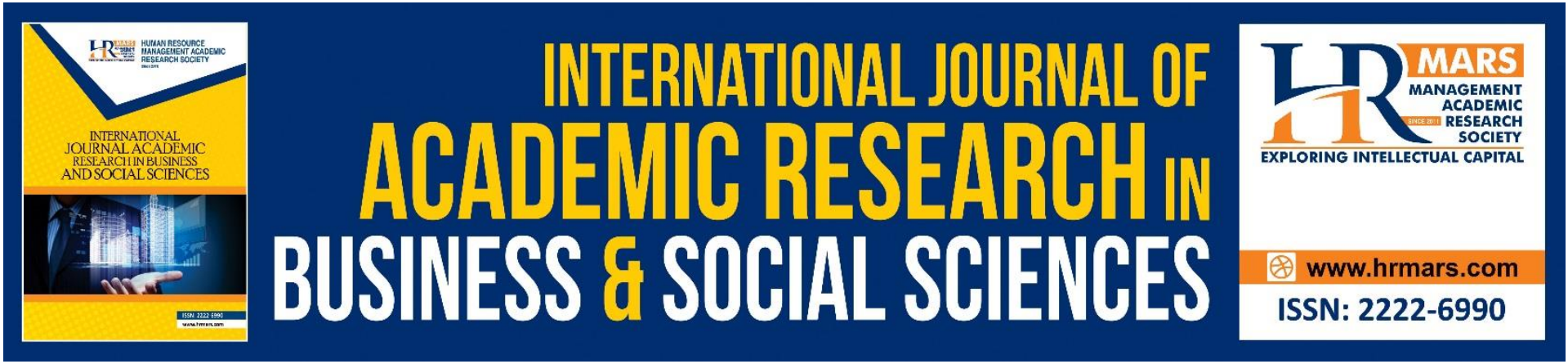

\title{
Exploration of Land and Power of Government: Syarak Perspective
}

\section{Zulkifli Mohamad, Nazri Muslim}

To Link this Article: http://dx.doi.org/10.6007/IJARBSS/v10-i11/8158

DOI:10.6007/IJARBSS/v10-i11/8158

Received: 17 September 2020, Revised: 20 October 2020, Accepted: 11 November 2020

Published Online: 24 November 2020

In-Text Citation: (Mohamad \& Muslim, 2020)

To Cite this Article: Mohamad, Z., \& Muslim, N. (2020). Exploration of Land and Power of Government: Syarak Perspective. International Journal of Academic Research in Business and Social Sciences, 10(11), 996-1005.

Copyright: @ 2020 The Author(s)

Published by Human Resource Management Academic Research Society (www.hrmars.com)

This article is published under the Creative Commons Attribution (CC BY 4.0) license. Anyone may reproduce, distribute, translate and create derivative works of this article (for both commercial and non-commercial purposes), subject to full attribution to the original publication and authors. The full terms of this license may be seen at: http://creativecommons.org/licences/by/4.0/legalcode

Vol. 10, No. 11, 2020, Pg. 996 - 1005

Full Terms \& Conditions of access and use can be found at http://hrmars.com/index.php/pages/detail/publication-ethics 


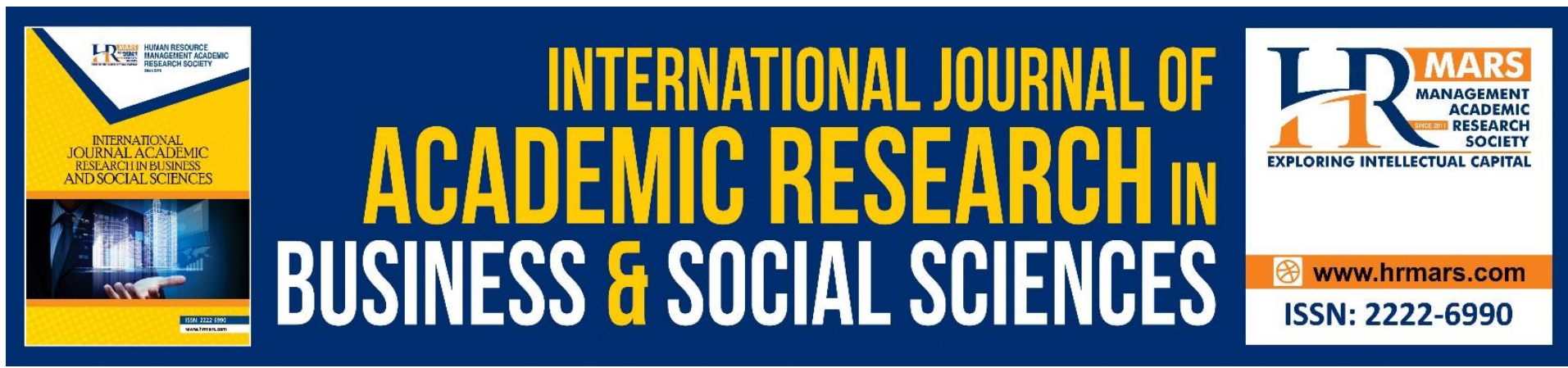

\title{
Exploration of Land and Power of Government: Syarak Perspective
}

\author{
Zulkifli Mohamad, Nazri Muslim \\ Pusat Citra, Universiti Kebangsaan Malaysia, 43600 Bangi, Selangor, Malaysia \\ Email: zulmadani@ukm.edu.my, nazrim@ukm.edu.my
}

\begin{abstract}
Land or property is a limited source of wealth. In Arabic it is known as the pronunciation of aqar, which is immovable property. Increasing the number of people in a country has led to an increase in land deals, while the price has become more expensive. Consequently, competent land laws can guarantee effective governance and ensure the well-being of all parties. The Federal Constitution and the National Land Law clearly provide land to the state government. The government is given the right to enact and amend land laws. The concept of ihya 'al-mawat also applies in the legal practice of our country. However, as our country develops rapidly, this concept has been updated to reduce aggression on government lands. The structured settlements that exist in our country like FELDA are a testament to the concept of ihya 'al-mawat. It is only through this concept that the power of the government in the matter of land disposal can be clearly seen and the government disposes of the land only to those who are qualified and entitled.
\end{abstract}

Keywords: Land, Federal Constitution, National Land Law, FELDA, Mawat.

\section{Introduction}

Land or property is a limited source of wealth. In Arabic it is known as aqar, which is immovable property. The increase in the number of people in a country resulted in land deals are becoming increasingly scarce, and the price is also becoming increasingly expensive. Thus, a competent land law can guarantee effective governance and ensure the welfare of all parties. Islamic scholars whether historical or contemporary, have been discussing the question of Aqar is beyond his time. The policies and principles of this discussion still remain relevant and widely applied in current land law. This article will try to discuss the most basic things to land ownership, namely the question of exploration by the people and the limitations of government authority to dispose of land to a person.

\section{Relationship Between the Federal Government and the State Government in Land Related Matters}

The National Land Code 1965 through section 40 places land under the state list. State lists are matters that are submitted to the states solely for the purpose of making laws. This list, among others, contains matters such as Islamic law and personal and family law for Muslims, agricultural land and forestry, local government outside the Federal Territory, services within 
local authority areas, state works and water works. State Government machinery, state holidays, investigations for state purposes, deprivation of any matter contained in the State List, turtles and fishing in the river.

From this State List it is clear that apart from local and religious matters, there is only one important matter that falls under state authority which is the question of land. Details of this matter include land tenure like the relationship between the landlord and the tenant; registration of title and deed of land; exploration; land development and land conservation; rental restrictions. Malay Reserve or in the Borneo states of the indigenous reserves. Permits and licenses to find minerals; mine leases and mine certificates. Forced land acquisition. Transfering of property ownership; broken promise; leases and mortgages on land; ismen and Return of property to government; treasures do not include antiquities. It is therefore clear that the state authorities are the authorities that have jurisdiction in almost all matters involving land.

In terms of land ownership and use categories, land is divided into four categories namely; state government land, mine land, reserve land and land owned either to individuals or to certain bodies (Hussin, 1996 ) .

The power to govern these matters is important, especially in Malaysia, where the economy largely depends on what is grown or dug from the ground. However, under the provisions of Article 76 (4), Parliament has been empowered for the purpose of determining the equality of law and policy 'making laws on land tenure, relationship between landlord and tenant, registration of title and deed relating to land, transfer land ownership, mortgages, leases and mortgages on land, cement and other rights and interests regarding land, taking land forcibly, on land rates and valuations and local government.

Federal and state relations on land issues are also touched on by the existence of the National Land Council which consists of a Minister as chairman, a representative from each state appointed by the King or Yang Dipertua Negeri and not more than ten representatives for the Federal government. It is the duty of the National Land Council from time to time to consult with the Federal government, state governments and the National Finance Council, to formulate a national policy to guide and regulate the use of land throughout the Federation. This policy is necessary for constitutional, agricultural, forestry, or any other purpose and to administer any law thereon. The Federal Government and the state government must follow the policy that has been formed.

Article 92 gives Parliament additional power over national development plans. A development plan is a plan to develop, develop or conserve produce in a development area, produce this product, or increase employment opportunities in that area. An area can be declared by the Yang di-Pertuan Agong as a development area 'if after a recommendation is received from an expert committee and after negotiations are held between the National Finance Council, the National Land Council and the government of any state concerned, the Yang di-Pertuan Agong satisfied that it is beneficial for the interests of the country to carry out a development plan in which area or area in one or several states and after publishing the plan. Then Parliament has the power to implement the development plan, including making laws on matters that only the state has the power to make laws. 
On other matters in the State List, Parliament may make laws if requested to do so by any State Assembly or for the purpose of establishing legal equality between two or more states. But in such cases, the Act of Parliament shall not take effect in any state until the law has been adopted by a law made by the State Legislature, then the law shall be deemed to be a state law, and not a Federal law. Therefore, the law may be amended or repealed by a law made by the State Legislature. Parliament may also make laws on any matter mentioned in the State List, without the consent of the state-

(a) for the purpose of implementing any treaty, agreement or convention between the Federation and any other country or any decision of an international organization of which the Federation is a member;

(b) for the purpose that the provisions of the Constitution of a thing be complied with;

(c) to make laws against subversive acts; and

(d) on emergency law.

It is clear that the state powers are very few. There is a strong tendency to centralization. Although in accordance with the provisions of Article 77 of the State Legislature has the power to make laws on any matter not mentioned in the Ninth Schedule List, the provision is not so effective as seen from the number and extent of matters that enable Parliament to make laws.

The division of powers of government is stated in Article 80 which states that the power of government for the Federation covers all matters which enable Parliament to make laws and the power of government for a state covers all matters which enable the State Legislature to make laws.

In line with the ambition to create a newly independent country, then the desire arose to create a uniform land law for the whole country. To this end, the International Development and Reconstruction Bank has set up a task force under Sir Louis Chick to review existing land laws and make recommendations to the government. A report was submitted in 1955, stating that the government needed to create a national land code to replace the existing different land laws ( Salleh Buang 1993 ).

\section{Land Ownership in Malaysia}

Malaysia is a Federal State. Administratively there is a Central Government and several State Governments that are members of the Federal Government. Article 1 (2) of the Federal Constitution states that Malaysia is a Federal country consisting of 13 State Governments namely Johor, Kedah, Kelantan, Melaka, Negeri Sembilan, Pahang, Perak, Perlis, Penang, Sabah, Sarawak, Selangor and Terengganu .

Article 2 of the Federal Constitution, on the other hand, allows Parliament to approve the entry of any state or amend the boundaries of a state into the Federation. The law must have the consent of the State concerned. For this purpose, the state boundaries of Selangor and Sabah have been amended to create the Federal Territory of Kuala Lumpur, Labuan and the Federal Territory of Putrajaya.

Constitution were provides few things most important to determine the administrative relations between the Federal Government and the State Governments. These provisions are 
important to prevent and resolve some disputes that may arise between the Federal Government and the State Governments. The Federal Constitution is the most important reference to resolve any dispute (if any) between the Federal Government and the State Governments (Muslim, 2017).

Based on the Federal Constitution, the relationship and division of power between the Central Government and the State Government, shows that the Central Government (Federal) has more power. This is the concept practiced in the Federal Constitution of Malaysia, based on the Report of the Reid Commission (Awang, 1994) .

The division of power between the Central Government and the State Government according to the Federal Constitution can be seen in two aspects below, namely:

\section{Division of Legislative and Governing Powers, and Land Matters}

Power over land is the most important right of the State Government. This power is a legacy since before independence, when each state has its own rules on its colonies. The different land laws between the states have caused many problems to all parties involved including land administrators, legal practitioners and the public. Therefore, the Federal Constitution has empowered Parliament to enact laws on land, with the intention of creating uniformity of law and policy. As a result, in 1965 the National Land Code was enacted by Parliament after long consultation with the State governments. This National Land Code, only applies to the peninsula because Sabah and Sarawak have their own land laws.

Parliament can make laws to empower the Federal Government provided it is approved by the State Legislative Assembly. On the other hand, Article 75 of the Constitution states, "If any State law is contrary to any Federal law, then the Federal law shall be applied and the law of the State shall be null and void, to the extent that it is contrary to law That federation ".

In this regard, the Federal Constitution has made several provisions regarding land. Article 76 (4) of the Federal Constitution reads as follows, "Parliament may, for the purpose of merely determining the equality of law and policy, make laws on land holders, the relationship between landlords and tenants, registration of titles and deeds in relation to land, transfer land, mortgages, leases and mortgages on land, ismen and other rights and interests regarding land, forcible land acquisition, on land rates and valuations, and local government...

Article 83 also outlines flood if the land required the Federal Government was not real property (alienated land), then negotiations should be held with the State Government which shall give the land to the Federal Government or to any public authority directed by the Federal Government. Nevertheless, if the land has been allocated (reserved) for the purpose of the State, the Federal Government can not take it unless the national interest. If the land required is land owned, it is the duty of the State Government to take possession of the land by agreement or by force in accordance with Article 83 (5) (b) of the Federal Constitution.

If the land that has been given to the Federal Government or to the Federal public authorities is no longer required, then the land can be returned to the State Government if it agrees to 
pay it. In the event of a dispute over the amount of payment, then this dispute may be referred to the Land Tribunal, as stated in Article 87 of the Federal Constitution.

Related Malay Reserve Land, it was one of Malay privileges established in accordance with Article 89 of the Federal Constitution. If any country has become a land of Malay Reserve Land before Merdeka Day in accordance with the existing law, the land may turn into Malay Reserve Land by law, but the law was amended. If any land in a state is not a Malay Reserve Land in accordance with existing laws and the land has not yet opened or operated, the land can be declared as Malay Reserve Land in accordance with the law. This can be done by holding an equally large area of land that has not been developed for public ownership. The total land area is reserved for the Malays in the country is not more than the total area of land for public property.

The State Government may declare any land taken by the government, by agreement with the landlord, as Malay Reserve Land. Landlords may also apply, with the consent of every person having an interest in the land, the land will be used as Malay Reserve Land. Similarly, if the land is no longer a Malay Reserve Land, the State Governments may declare other land has the same size and type as Malay Reserve Land.

The Constitution also empowers the Federal Government to take land for national development and this land will be declared by the Yang DiPertuan Agong as land area for development when certain regulations are implemented. To carry out this development plan, Parliament and the State Legislative Assembly may impose taxes or rates permitted by the Constitution and may also approve the granting of money from the Consolidated Fund. For Sabah and Sarawak, the provisions of Article 89 do not apply because Article 161 A (5) clearly empowers the States to make laws on reserve land for Bumiputeras there.

The basis of the above division of power between the Federal Government and the State Government in both the above aspects is determined in Articles 74 to 95E and the Ninth Schedule, Federal Constitution of Malaysia.

\section{Land Disposal}

As the absolute owner of government land, the State Authority has extensive disposal powers in accordance with the provisions of section 42 of the National Land Code. The power of disposal available to the State Authority is contained in section 42 of the National Land Code, as follows:

(a) Grant ownership of government land for a period not exceeding 99 years or for ever in accordance with section 76 KTN;

(b) Reserve government land and lease reserve land;

(c) Grant permits to occupy government land, reserve land and mine land;

(d) Authorize the production and transfer of rock material from any land other than forest reserves;

(e) Allow the use of airspace on government land or reserve land. 
If refined in depth, it is clear that there are two different types of disposal powers under the provisions of the National Land Code (KTN), namely the first 'disposal with ownership' and the second 'disposal other than grant'.

\section{Disposal with the Grant of Title}

Disposal with this grant means that the state authority gives ownership of the land permanently or for a specified period to any recipient who meets the conditions set according to KTN. Section 76 of the National Land Code states as follows:

According to the current government's policy, the grant of land ownership is practiced only for the term of ownership, that is, for a period not exceeding 99 years. Permanent granting is no longer practiced after the Amendment Act A587 is passed, which has been in force since March 25, 1985. Prior to that date, the State Authority is free to grant land ownership as permanent ownership either to individuals or to any corporation. Pursuant to section 76 of the National Land Code, the grant of permanent ownership is still practicable, but limited to the following circumstances:

(i) where the Federal Government requires the State Authority to grant permanent ownership to the Federal Government or public authorities or if the Government and the State Government agree to grant a permanent grant to the Federal Government;

(ii) where the State Authority is satisfied that the land will be used for public purposes; or

(iii) where the State Authority is satisfied that there are special circumstances requiring ownership forever.

The granting of land ownership, either for a specified period of time or a permanent grant of ownership, is generally subject to the following conditions:

(i) The owner shall pay premiums (once only) except exemptions, survey fees and charges for other matters relating to the preparation and registration of title documents, annual tax for the first year and subsequent payment of land tax each year without fail;

(ii) Titled land will be placed under certain land use categories in accordance with the requirements of section 52 of the National Land Code and will be subject to conditions and restrictions of interest as determined by the State Authority.

\section{Government Permission to Explore Land}

Although Islam allows the exploration of mawat land as a means of land ownership by a person, however the role of the government in controlling the course of such activities must be taken into account. Therefore, the issue arises whether it is necessary to ask permission from the government before starting work on the development of dead land. Abu Hanifah thinks that it is necessary to ask permission from the government before exploring a field of land, and majority fuqaha including Abu Yusuf think that the people are free to ihya mawat land without having to ask the government's permission.

\section{Those Who Think They Need the Government's Permission}

According to Abu Hanifah (al-Mawardi 1990 ) government permission was required before the ihya land effort was started. Abu Hanifah does not agree with the existence of the concept of ihya independently. Abu Hanifah argues that the permission of the government should be sought based on hadith which means, "A person is not entitled as long as he has not received 
the permission of the government" (Wahbah al-Zuhayli 1989). In the opinion of Abu Hanifah, the permission of the government can be used as a backup and reference if something undesirable arises later (Yusuf, 1382H).

According to Abu Hanifah again, when the Muslims succeeded in conquering the infidel country, the status of the captured mawat land was fay category and no session was entitled to fay land individually, instead the land was under government control like ghanimah property (Ali, 1413H) .

Abu Hanifah also rejects the analogy of comparing land ownership and animal ownership because the two are not the same type of property. In Islam, whoever hunts an animal that does not belong to anyone, then the animal will become his. Abu Hanifah says that the provision that allows the ownership of property by hunting animals cannot be compared with mawat land because the animal did not originally belong to the infidels. Thus animals can be owned by means of istila but different from the case of land that was originally owned by infidels. Therefore, the government's permission must be obtained before exploring the land.

Accordingly al-Dusuqi $(1382 \mathrm{H})$ requires that the permission of the government be required when the mawat land is close to residential areas or near cities. On the other hand, if the mawat land is far from the residential area, there is no need to ask permission from the government. For mawat land near the public settlement area, no one is allowed to explore it when they do not get the government.

\section{No Need to get Government Permissions}

Majority fuqaha including Abu Yusuf $(1382 \mathrm{H})$ argued that permission from the government to develop land was not necessary, because hadith Rasulullah saw himself did not require the need to ask for government permission. On the other hand, it is sufficient to explore the land as the Prophet saw said:

What is the purpose of life? which means:

"Whoever revives the dead land then the land becomes his own" (Abu Dawud 1988).

Abu Yusuf was of the opinion that the practice of exploring the mawāt land was enough to own the land without the need for permission from the government by qiyas kan ownership rights over the animals with the hunting activity itself. Whoever hunts an animal and succeeds in capturing the animal then the animal will be his (al-Zaylai $(1413 \mathrm{H})$.

Ibn Qudamah (1989); al-Bahuti (1394H) and al-Khatib al-Syarbini (1958) argued that there was no need to ask permission from the government because idle land was included in the category of mubah items that could be owned by exploring it. That is why idle land is entitled to be owned by anyone. Furthermore hadith Rasulullah saw did not say the need to ask for permission from the government. However, al-Khatīb al-Syarbini encouraged getting permission from the government to avoid disputes or hardships in the future.

\section{Government Authorization and Practice in Malaysia}

At the moment in the Malaysian context, the land area is increasingly insufficient to meet the growing needs of the population. Land is a limited resource but the population is growing. 
Therefore, the opinion of Abu Hanifah which requires the need for government permission is more suitable to be used so that there is no land grabbing and oppression of the weak.

The opinion of Abu Hanifah which requires the need for government permission before developing mawat land is more appropriate to be given at this time. This method is a measure to prevent injustice from the control of land and so that the country's lands are not controlled by a handful of able-bodied people while the land is public property. Government permission can avoid any problems in the future, because the land explored with the government's permission is more formal and the other party does not have the right to violate the ownership of the land explored by someone.

\section{Conclusion}

Referring to the Federal Constitution and the National Land Code, clearly allocates land to the state government. The government is given the right to enact and amend the law on land. The concept of ihya 'al-mawat also applies in the practice of law in our country. However, after our country developed so rapidly, this concept has been updated to reduce encroachment on government lands. The structured placement plan available in our country such as FELDA is a proof of the concept of ihya 'al-mawat. Through this concept can only be clearly seen the power of the government in the matter of land disposal and the government only disposes of land to those who are eligible and entitled only. In Malaysia, the state government has power over land-related matters. No individual is allowed to occupy any government land without permission. In the case of the placement of the ground plan structured as Felda settlers should apply, attend the interview had expected and the successful candidate will get state permission to participate in the development plan of the land and can not explore any arbitrary ground we na unfortunately. The Federal Constitution of Malaysia has given power to manage land affairs to the state government. The Federal Government itself does not have the right to take land without the consent of the state government, let alone to own and give ownership to the people.

\section{References}

Abu Dawud, S. (1988). Sunan Abu Dawud. Kaherah: Dar al-Rayyan.

Al-Buhuti, M. (1394H), Kashaf al-Qinan Matan al-lqna, Makkah: al-Mațbaah al-Hukumiyyah. Al-Dusuqi. (1382H). Hasyiyah al-Dusuqi ala al-Syarh al-Kabir. Beirut: Dar al-Kutub al-Ilmiyyah. Al-Mawardi. (1990). al-Ahkkam al-Sultaniyyah wa al-Wilayah al-Diniyyah. Beirūt: Dar al-Kitab al-Arabi.

Al-Sanani, M. (1987). Subulu al-Salam Syarḥ Bulugul al-Maram min Jami Adillah al-Aḥkam. Iskandariyyah: Dar al-Rayyan.

Al-Syarbini, M. (1958). Mughni al-Muhtaj ila Marifat Maani Alfaz al-Minhaj. Beirut: Dar Ihya' al-Turath al-Arabi.

Al-Syawkani, M. (1382H). Nail al-Awțar Syaraḥ Muntaqa al-Akhbar. Kaherah: Mațbaah Muștafa al-Babi al-Ḥalabi wa Auladih.

Al-Tirmidhi, A. (1413H.), al-Jami al-Șahih. Beirut: Dar al-Kutub al-Ilmiyyah.

Al-Zaylai, F. (1413H), Tabyin al-Haqa'iq Syarh Kanz al-Daqa'iq. Beirut: Dar al-Kutub alIlmiyyah.

Al-Zuhayli, W. (1989). al-Fiqh al-Islami wa Adillatuhu. Damsyik: Dar al-Fikr.

Awang, M. R. (1994). Undang-undang Tanah Islam Pendekatan Perbandingan. Kuala Lumpur: Dewan Bahasa dan Pustaka. 
Bang, S. (1993). Undang-undang Tanah di Malaysia. Kuala Lumpur: Dewan Bahasa dan Pustaka.

Beng, O. K. (2007. Bukan Kerana Pangkat: Tun Dr. Ismail dan Masanya, Singapore: Institute of Southeast Asian Studies.

Husin, A. A. (1996). Undang-undang Tanah: Lesen Pendudukan Sementara dan Permit. Kuala Lumpur: Dewan Bahasa dan Pustaka.

Ibn Qudamah, A. (1989). al-Mughni al-Kabir., Kaherah: Ḥajar li al-Ṭibaah wa al-Nasyr.

Muslim, N. (2017). Islam dan Melayu Dalam Perlembagaan Persekutuan Tiang Seri Hubungan Etnik di Malaysia. Bangi: Penerbit UKM. 